\title{
SELECTED ASPECTS OF BUILDING , OPERATION AND ENVIRONMENTAL IMPACT OF OFFSHORE WIND POWER ELECTRIC PLANTS
}

\author{
Adam Mroziński, Ph. D. \\ Izabela Piasecka, Ph. D. \\ University of Technology \\ and Life Sciences in Bydgoszcz, Poland
}

\begin{abstract}
This paper describes essence of work of offshore wind power electric plants and crucial aspects of their building and operating. Prospects for development of global, European and domestic markets of offshore wind power industry have been delineated. A comparative analysis of environmental impact of an offshore and land-based $2 M W$ wind power electric plant has been performed by using LCA method and Ecoindex - 99 (Ekowskaźnik 99) modelling.
\end{abstract}

Keywords: wind energy, offshore wind power electric plants, LCA method , Ekowskaźnik 99 (Ecoindex - 99)

\section{Introduction}

Offshore wind power industry plays greater and greater role in the process of providing safety of power supply for Europe. As results from the document of European Commission titled: Offshore wind energy: Activity necessary for reaching aims of energy policy in the perspective up to the year 2020 and further, $40 \%$ of energy production potential connected to network comes from wind power industry. For possible development of offshore wind power industry in Poland it is crucial to have possibility of adjoining new installations to Domestic Electric Power System, to organize own port and shipyard back-up facilities and a stable, effective system for supporting renewable energy sources $[7,16]$.

Economic conditions and administrative and legal difficulties have been so far substantial obstacles in developing offshore wind power industry. In Poland first steps towards creating favourable legal conditions for offshore sector have been done just in the last years. Owing to changes introduced into the Act on Polish sea territories and maritime administration, in 2011 new conditions for the siting of offshore wind power installations on Polish sea territories came into effect. Area of Polish sea territories amounts to about 33 thousand $\mathrm{km}^{2}$, however the total area of sea waters determined by the ministry responsible for maritime economy as potentially accessible for offshore wind power industry, amounts to over $2.000 \mathrm{~km}^{2}$. The first offshore wind farm planned to be built in Poland, will have its rated power of about $100 \mathrm{MW}[7,8,16]$.

\section{Major aspects of building the offshore wind power electric plants}

Offshore wind farms are consisted of groups of windmills of different number of units. A single offshore wind power electric plant contains a foundation, tower, nacelle and rotor. There are several different design solutions of building the windmill foundations. Their applications depend on water depth and sea bed geological structure in site . Most often applied kinds of foundations are : monopile (74\%), (16\%), jacket (5\%) and tripods (2\%) (Fig. 1 and 2) [3, 5, 9].

The monopile is the most often chosen kind of foundation because of its low cost, simplicity and possible implementation in shallow waters (less than $20 \mathrm{~m}$ deep). Installation of a monopile does not require any preparation of sea bed - the pile is drilled or driven in it. Monopiles cannot be used in case of sandy bottom or in places where boulders occur. GBS (gravity foundation) has been applied in the beginning of development of wind farms in shallow waters (about $15 \mathrm{~m}$ deep), in present they are being adjusted to greater and greater water depths (up to about $30 \mathrm{~m}$ ). The technology is based on a large surface and mass of foundation that secures the windmill against wave and wind forces. They are almost entirely manufactured on shore with the use of concrete and steel. The tripod is a structure which makes use of the same solution as that applied to monopiles. Its base is supported on three columns - this way it can be used in deeper waters. Three ends of the base are seated on or driven into sea bed to support central part of the facility connected with turbine. 
The jacket, in contrast to tripods, is consisted of a more spread structure of steel bars symmetrically arranged beyond the main axis of the entire structure. It leads to a significantly lower consumption of materials $[3,5,16,17]$.

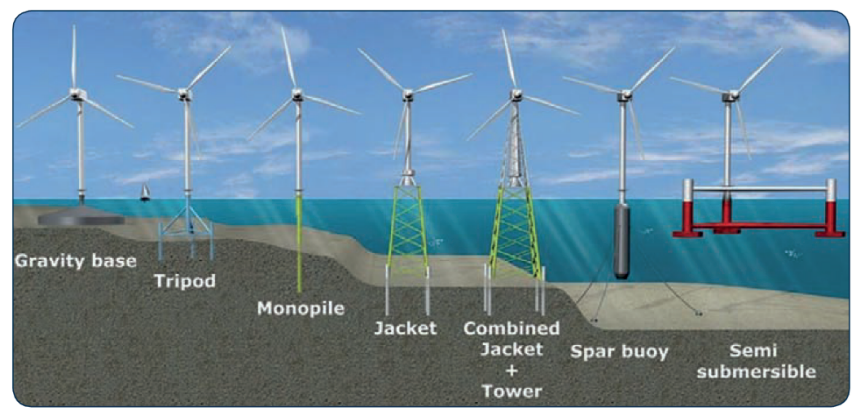

Fig. 1. Various solutions of anchoring the offshore wind power electric plants, depending on water depth [3]

Offshore wind power industry is now in the phase of permanent technological development. Owing to investments into new technologies its continuous evolution can be observed in this sector. Floating foundations which are now under tests, may exemplify this trend. It is expected that, due to development of the solution, the limitations associated with water depth and sea bed structure will be overcome $[16,22]$.

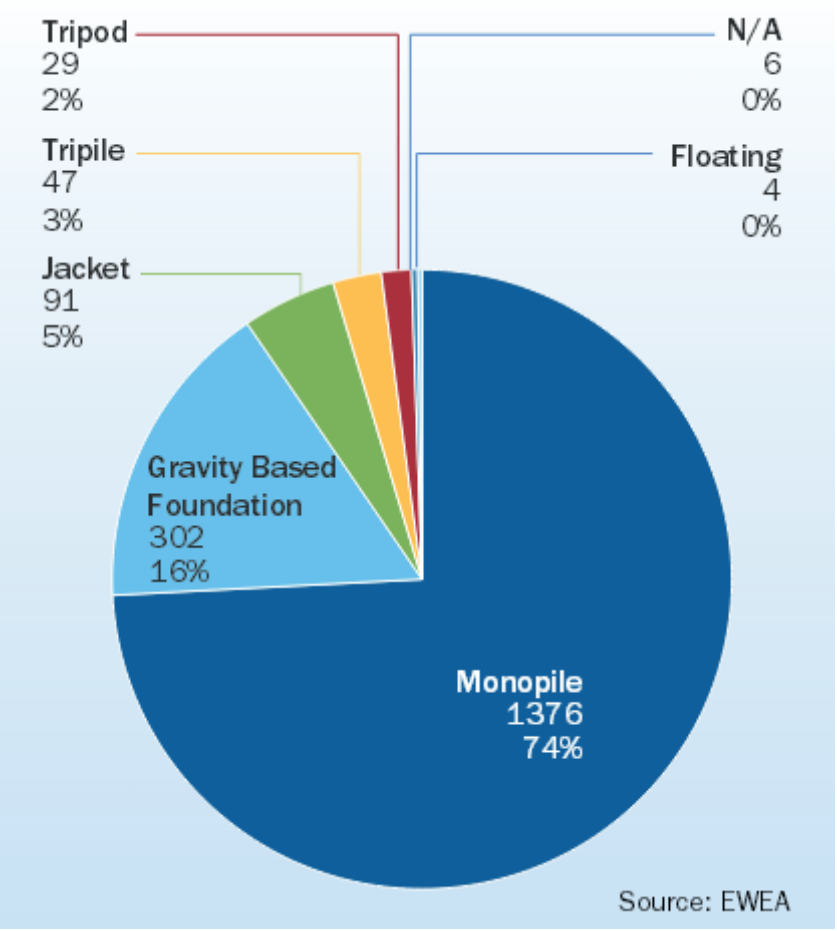

Fig. 2. Relative amount of power installed in 2012, depending on an applied manner of the anchoring of foundation of offshore wind power electric plant [9]

\section{Selected aspects of operation of offshore wind power electric plants}

Regardless of many obstacles indispensably connected with using the offshore windmills, they are expected to form the future of all wind power industry. Main differences between offshore and land - based wind turbines result from two factors: marine environment and high cost of installation. Each of them influences characteristic features of wind farm. Presently investment cost of offshore installation is by $30 \div 50 \%$ greater than that of analogous one but based on land. Marine environment requires a special approach to turbine design, which takes into account higher corrosion resistance, design of supporting structure, higher power output, maintenance issues and resistance to heavy weather. Against salt mist corrosion effects, protection means are undertaken in the form of corrosion resisting devices and materials (also application of parts made of stainless steel and glass reinforced plastics- GRP), specialty coating systems for marine applications and accommodations with filtered and conditioned air. Tower anchoring manner and construction for windmills must take into account such factors as: sea tides and currents, height and impacts of waves, possible collisions with ships and icebergs, increased turbulence and wind force during storms. Construction of marine structures is based on principles determined by oil mining industry, adjusted to specificity of offshore wind power electric plants. During erection of an offshore wind farm also ecological aspects are extremely important, especially non-disturbance of ecosystem in waters where a wind farm has to be placed. Wind farms cannot be located along bird flying routes and also more strict preventive means are applied against oil leakage from mechanical devices to sea water (possible in case of an uncontrolled failure) [2, 6, 11, 13, 24, 25].

Among their main drawbacks the following may be distinguished: a more difficult access to objects in comparison to those based on land, a much higher cost of foundation building and wiring to an electric power network, much more expensive maintenance and servicing, necessity of limitation maintenance operations to a minimum (high cost), application of turbines of a much expensive, higher quality in order to limit servicing and replacement of parts, as well as the use of corrosion and erosion preventing means potentially hazardous to the environment, but necessary for construction and foundations. The servicing and maintenance of offshore wind farms is more challenging and costly than in case of land based installations. Duration of maintenance operations reaches $40 \div 50 \mathrm{~h}$. Major repair is conducted every fifth year on average, and its expected duration takes about $100 \mathrm{~h}$. Turbines are from time to time not accessible because of strong winds or a low visibility. Experience with offshore wind farms has shown that weather problems make it impossible to perform about $15 \%$ scheduled O\&M visits (Operations \& Maintenance) $[4,14,15]$.

The most important principle of technological development of wind farms is safety of their building. Design features considered in this aspect contain: a permanent integrated platform above splashing zone, fenders absorbing energy of 
bumping, elastic gangway ladders for traffic between a ship and turbine, cranes to pull ships closer in case of occurrence of high waves, as well as hoisting and transporting means for carrying personnel and equipment. Certain producers introduce into market a kind of windmills which allow to limit conservation requirements at a simultaneous rise in their reliability and effectiveness, however at the expense of increased cost of the turbine. The features cover also application of direct - drive electric generators (which eliminate transmission gear, i.e. the component most liable to mechanical failures), generators with permanent magnets, which generate a higher voltage and eliminate necessity to install transformers (reducing this way energy losses), entirely covered generators secured this way against effects of marine salty environment, as well as electric control over reduction of deviations, setting the angle of attack of rotor blades, and braking systems in order to eliminate problems occurring in hydraulic systems $[1,10,14,15]$.

The following advantages of offshore wind installations may be considered most important: a more stable action of sea wind, which allows to make use of turbines more effective, a greater wind force at a lower height over sea, which allows to apply towers of a lower height, rise of wind force along with growing distance off the coast, more siting areas, reduction of landscape devastation to a minimum, as well as a limitation of excessive noise close to living buildings, an increase in number of workplaces in comparison with land investments as well as a positive impact on quality of the environment owing to avoidance of contamination emission and the use of a renewable energy source $[1,5,15]$.

Main parameters of wind, which influence windmill capacity of generating electric power are: its average and maximum speed, turbulence and drop- offs. Average and maximum wind speeds are greater over sea than land (Fig. 3). Vertical drop-off of wind represents difference in wind speed in relation to difference in level. The wind drop-off is affected by friction of air flow on surface of ground, buildings and other objects which reduce its velocity. In case of offshore wind power electric plants number of potential friction sources is much lower. Similar environmental turbulences due to unevenness of ground surface do not occur at sea $[1,5,20]$.

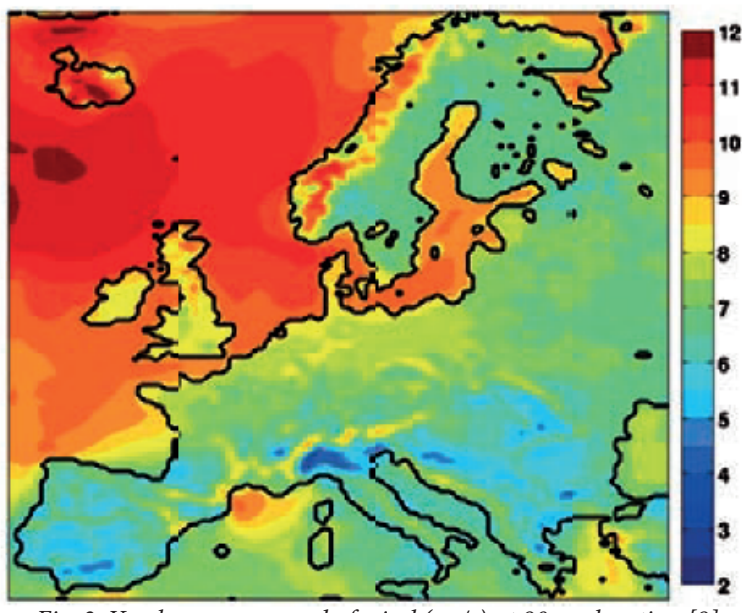

Fig. 3. Yearly average speed of wind $(\mathrm{m} / \mathrm{s})$ at $90 \mathrm{~m}$ elevation [9]
Offshore windmills may be also especially favourable for certain aqueous organisms. Fishes may find shelter there since in the wind farm areas the fishing net trawling which can devastate sea bed and endanger organisms living there, is prohibited. The windmills may also be a friendly environment for edible mussels and many kinds of crabs. It is indisputable and beneficial that electric power plants of this kind make acidification of oceans lower by contributing in abatement of $\mathrm{CO}_{2}$ emission to the atmosphere. However further cooperation of developers, ecologists and scientists dealing with seas and oceans, in the area of research on the impact of windmills onto sea life, is necessary $[3,8]$.

\section{Development of offshore wind power industry}

Offshore wind power industry is one of the fast developing energy markets in the world. It has been more than 20 years ago when the first in the world wind farm of $5 \mathrm{MW}$ output has been built in Vindeby, Denmark. In Europe over $5 \mathrm{GW}$ electric power generated by offshore wind farms was till now installed, including the amount of over $90 \%$ coming from the North, Baltic and Irish Sea and the English Channel [9, 13]. Among the remaining locations the investment projects sited close to the east coast of China, may be distinguished. Such investment projects become more and more popular in Japan, USA, Canada, Taiwan and India. According to the expectations, up to 2020 even $80 \mathrm{GW}$ new power sources are possible to be installed worldwide. In 2012 the market grown by $1.296 \mathrm{MW}$, i.e. by $33 \%$ in relation to its level in 2011. Most of the growth (90\%) come from installations in Europe, mainly in Great Britain, Denmark, Belgium, Germany, the Netherlands and Sweden (Tab. 1) [3, 9].

Till 2010, development of offshore wind farm projects has been concentrated on relatively low water depths (up to $10 \mathrm{~m}$ ) and close-to-shore areas (up to $20 \mathrm{~km}$ ). Permanent development of technology and growing experience of firms investing into wind power sector have caused that offshore installations are presently sited in areas more and more distant off shore and deeper and deeper waters. For the projects of wind farms executed in 2010 the average water depth amounted to $20 \mathrm{~m}$, and the distance to shore $-30 \mathrm{~km}$. It is expected that till 2030 wind farms would be sited in water areas $60 \mathrm{~m}$ deep and $60 \mathrm{~km}$ distant off shore. There are also prospects of making use of even more distant water areas (over $60 \mathrm{~km}$ ), which may be exemplified by German and British projects (Round 3) (Fig. 4) [9]. According to forcasts of European Wind Energy Association the future of the sector of renewable energy sources belongs to offshore facilities. Prior to 2030 power output received either from offshore or land - based windmills may be comparable to each other [9].

\section{Development prospects for Polish offshore power industry}

In Poland, according to the amended act on Polish sea territories, offshore wind farms are allowed to be sited only in the area of exclusive economic zone, i.e. in the distance of 22 $\mathrm{km}$ off shore. Polish exclusive economic zone covers the area 
Tab. 1. Power output of installations in European offshore and land-based wind power industry in 2012

\begin{tabular}{|l|r|r|r|}
\hline \hline Country & $\begin{array}{l}\text { Land } \\
\text { Installat } \\
\text { lonsss }\end{array}$ & $\begin{array}{l}\text { Offshore } \\
\text { Installat } \\
\text { onsse }\end{array}$ & \multicolumn{1}{l|}{ Total } \\
\hline Austrla & 1.387 & 0 & 1.378 \\
\hline Belglum & 996 & 380 & 1.375 \\
\hline Bulgarla & 684 & 0 & 684 \\
\hline Cyprus & 147 & 0 & 147 \\
\hline Denmark & 3.241 & 921 & 4.162 \\
\hline Estonla & 269 & 0 & 269 \\
\hline Flnland & 262 & 26 & 288 \\
\hline France & 7.564 & 0 & 7.564 \\
\hline Greece & 1.749 & 0 & 1.749 \\
\hline Spain & 22.796 & 0 & 22.796 \\
\hline Holland & 2.144 & 247 & 2.391 \\
\hline Ireland & 1.713 & 25 & 1.738 \\
\hline Llthuanla & 225 & 0 & 225 \\
\hline Luxemburg & 45 & 0 & 45 \\
\hline Latvla & 68 & 0 & 68 \\
\hline Malta & 0 & 0 & 0 \\
\hline Germany & 31.027 & 280 & 31.307 \\
\hline Poland & 2.497 & 0 & 2.497 \\
\hline Portugal & 4.523 & 2 & 4.525 \\
\hline Czech Rep. & 260 & 0 & 260 \\
\hline Romanla & 1.905 & 0 & 1.905 \\
\hline Slovakla & 3 & 0 & 3 \\
\hline Slovenla & 0 & 0 & 0 \\
\hline Sweden & 3.582 & 164 & 3.745 \\
\hline Hungary & 329 & 0 & 329 \\
\hline G.B. & 5.497 & 2.948 & 8.445 \\
\hline Italy & 8.144 & 0 & 8.144 \\
\hline All & 101.048 & 4.993 & 106.041 \\
together & & & \\
\hline
\end{tabular}

Source: acc. the authors'own work based on [9] of about 22,5 thousand $\mathrm{km}^{2}$. Theoretical potential of Polish wind power resources amounts to about $130 \mathrm{GW}$, however it is not practically possible to make use of the whole potential as its estimation has been based on the total area of internal waters and territorial sea. Its technical potential is limited to about 7,5 GW as present limitations for the siting of wind power electric plants in sea areas are much stringer than for land areas. In view of technical possibilities of building wind power electric plants (i.e. sea water depth) and possible conflicts in using the sea space, only a small part of the area (up to $5 \%$ ) is deemed to be available for building offshore wind power electric plants up to 2020. Environmental limitations associated with inclusion of large fragments of Polish sea waters into NATURA 2000 network deal consequently also with the sea waters in question, nevertheless the entire area is characteristic of favourable wind conditions. As assumed for offshore wind power electric plants, their whole technical potential may be utilized with a satisfactory economic effect (Tab. 2) $[16,20]$.

Tab. 2. Predicted potentials of Polish offshore wind power industry

\begin{tabular}{l|l|l}
\hline Potential & Power & Energy[TWh] \\
& {$[\mathrm{GW}]$} & \\
\hline Theoretical potential & 130 & 380 \\
Technical potential & 130 & 380 \\
Technical potential under limitations & 20 & 60 \\
Economic potential & 7,5 & 22,5 \\
Market potential in 2020 & 1,5 & 4,5 \\
\hline
\end{tabular}

Source: acc. the authors' own work based on [16]

Poland has one of the biggest market potentials of wind farms on the Baltic Sea. As the calculations performed a.o. by the University in Oldenburg, show, the area of Polish exclusive economic zone is one of the territories of the best wind conditions on the Baltic Sea. European Wind Energy Association has estimated that Sweden and Poland, out of all European countries, may install the greatest wind power by 2030 , (Fig. 5 ) $[9,20]$.

In present, a consortium of private firms has formulated the first development foresight of offshore electric network connecting future wind farms. After preliminary deliberations with authorities responsible for environment protection and land - space economy, have been identified three possible spots where marine electric power cables could be laid onto land; they are located close to Lubiatowo (Choczewo commune, Wejherowo administrative unit, Pomeranian province), Ustka (Ustka commune, Slupsk administrative unit, Pomeranian province) as well as Grzybowo (Kołobrzeg commune, Kolobrzeg administrative unit, West Pomeranian province). For siting offshore windmills altogether 109 places of a total surface area equal to $2503,45 \mathrm{~km}^{2}$ have been selected, namely in the neighbourhood of Odra Bank (25 places, 637,98 $\mathrm{km}^{2}$ ), Southern Middle Bank (22 places, 501,61 km²), Żarnowiec (12 places, 284,22 $\mathrm{km}^{2}$ ) as well as Slupsk Bank (50 places, $\left.1079,64 \mathrm{~km}^{2}\right)[8,16,18]$. 


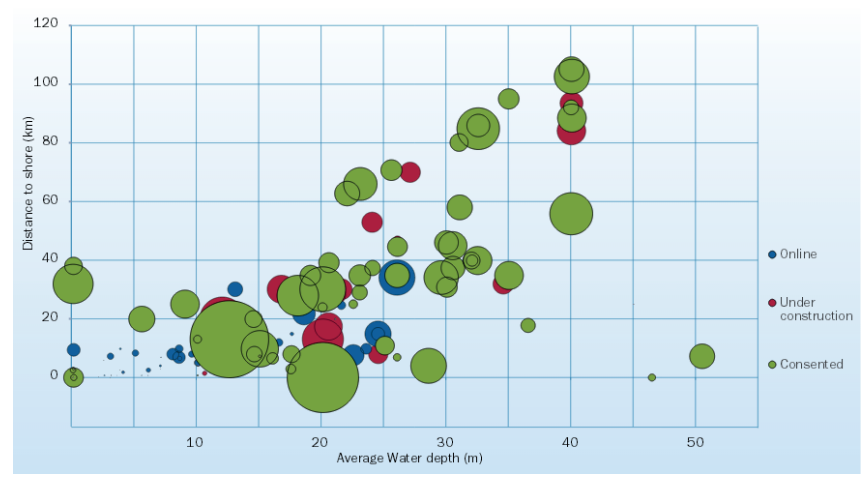

Fig. 4. Development trends in offshore wind power industry in function of distance to shore and water depth in site of new installations [9]

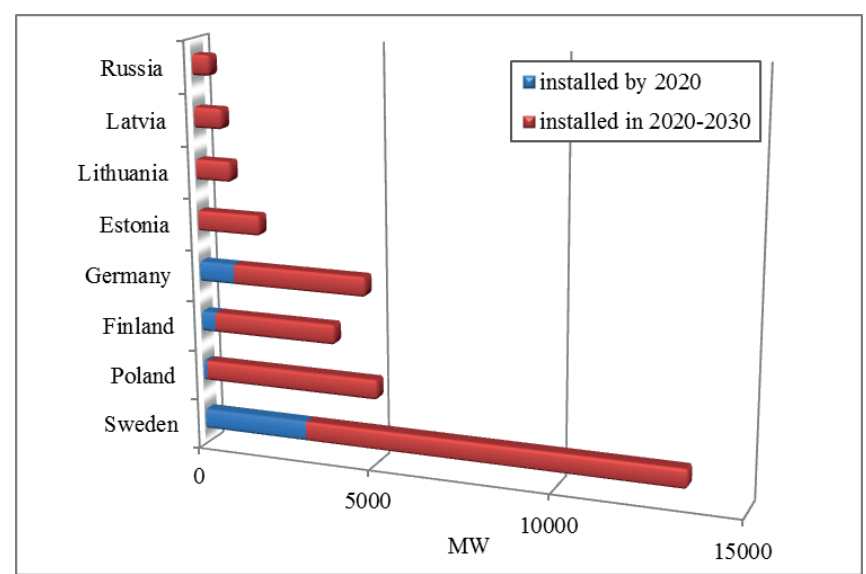

Fig. 5. Scenario of location of wind farm installations on the Baltic Sea up to 2030 Source : acc. the authors' own work based on [9]

\section{Research methods}

The method of environmental assessment of life cycle of products (LCA) serves as a tool for quantitative determination of environmental impact. It is based on collecting environmental factors dealing with a given object. They may also relate to a definite process or other activity conducted within the life cycle beginning from winding up to final recycling. The LCA method makes it possible to identify and assess emission of noxious substances, consumption of materials and energy during all life phases of a given technical object [12, 21].

An Ecoindex - 99 (Ekowskaźnik 99) method has been applied to characterize environmental impacts of wind power electric plants. It was developed by an international team of experts representing different European countries (in 1999). It has found application to calculation of maximum detrimental effects onto the environment which may occur on European territory. Some of the processes taking place there have an influence also on global situation. For this reason they are taken into account in calculating the effects in question. Among them the following are counted a.o.: a damage resulting from ozone layer depletion and greenhouse effect, emission of carcinogenic substances as well as changes occurring in natural resources worldwide. An important factor which influences shape of Ecoindex 99 results is the system of three spheres affecting life cycle: ecosphere, technosphere and evaluation sphere. In the Ecoindex 99 method all the three are taken into consideration to the same extent. Life-cycle model is formulated in technosphere and its results are presented in an inventory table. It is associated with three damage categories modeled in ecosphere. The evaluation sphere is used for assigning appropriate weights in order to obtain a reliable index. When using the Ecoindex 99 method, the following damage categories in which environmental impacts obtained during analysis phase undergo assessment, have been selected on the basis of definition of the environment: ecosystem quality, human heath and natural resources [12, 19].

In the considered investigations a 7.1 SimaPro software prepared by PrèConsultants firm, was used. It makes it possible to assess an impact of a given technical object onto the environment during one cycle of its life or solely during its production or operation. It is also possible to conduct comparisons between many objects. Life cycle of an object under consideration is divided into three phases: its production, operation and post-use waste disposal. In each of the phases an amount and kind of used materials, energy and applied technological processes should be defined in compliance with the model. On the basis of the so formed lifecycle model, the software, by making use of the attached data bases, calculates a quantitative impact onto the environment from the side of particular chemical compounds. The impact is manifested in the form of emission of the substances or their absorption from the environment. The emissions and absorptions are grouped into four fields under impact. The emission fields are: air, water and ground, and the absorption field covers raw materials [12].

Two $2 \mathrm{MW}$ windmills, one land-based and the other offshore - sited (of monopile type) were subjected to the investigations. In the case of the land windmill its tower was built of steel plates and concrete. Its rotor consisted of three blades, boss and cap. The blades were made of a glass-reinforced epoxy resin (GRP). The entire structure was upgraded by using carbon fibres. The boss was of spherical form and made of spheroidal cast iron. It was assembled directly onto main shaft and had a hole for internal inspection and maintaining hydraulic system in motion. The boss and blade bearings were entirely covered and secured against exposure to external environmental effects by means of a boss cap made of GRP. The nacelle consisted of a cover and load-carying frame, electric generator, transmission gear, transformer, inclination system and electronic system for control and steering. It was made mainly of copper and steel. Its cover, made of GRP, was intended for the protecting of mechanical elements against external environment impact. The remaining equipment of the nacelle was first of all made of steel and, to a smaller extent, of aluminium, copper, GRP and epoxy resins. Foundations of the typical size $15 \times 15 \times 2 \mathrm{~m}$, were built of concrete and steel. Construction of the offshore windmill was analogous with the exception that a steel 
monopile was used instead of the concrete foundations. Its life cycle was assumed to reach 25 years and location was limited to the European territory.

\section{Results and their analysis}

The analysis of harmful impact levels of the offshore wind power electric plant on the environment, has demonstrated, in comparison with the land - based windmill, its higher negative effects in the category of carcinogenic compounds (0,284 DALY), organic compounds impairing respiratory system (0,002 DALY), substances causing climatic changes (0,379 DALY), radioactive elements (0,0172 DALY) as well as ecotoxic substances $\left(1.320 .083,6 \mathrm{PAF}^{\star} \mathrm{m} 2 \mathrm{yr}\right)$. In the six remaining impact categories the land - based wind power turbines showed a higher level of harmful impact (Tab. 3).

In the Ecoindex 99 method, results of the grouping and weighing are presented in the unit of environmental points $(1 \mathrm{Pt})$. One thousand of environmental points represents the environmental impact exerted by an average European per one year [12].

Tab. 3. Results of the assessment of environmental impact characteristics of $2 M W$ wind power electric plant, either land-based or offshore one, by using Ecoindex-99 method [acc. the authors' own work]

\begin{tabular}{l|l|l|l}
\hline Impact category & $\begin{array}{l}\text { Land based } \\
\text { wind power } \\
\text { plant }\end{array}$ & $\begin{array}{l}\text { Offshore } \\
\text { wind power } \\
\text { plant }\end{array}$ & Unit \\
\hline Carcinogens & 0,21495017 & 0,28414975 & DALY \\
Resp. organics & 0,001658914 & 0,001733158 & DALY \\
Resp. inorganics & 1,210748 & 0,95415158 & DALY \\
Climate change & 0,35093005 & 0,37922162 & DALY \\
Radiation & 0,010232855 & 0,010761077 & DALY \\
Ozone layer & 0,000673284 & 0,000583665 & DALY \\
Ecotoxicity & 879423,9 & 1320083,6 & PAF*m2yr \\
Acidification/Eutrophicat & 29954,917 & 25882,851 & PDF*m2yr \\
Land use & 10910,827 & 7562,7153 & PDF*m2yr \\
Minerals & 512922,39 & 504011,09 & MJ surplus \\
Fossil fuels & 2437145,9 & 1752643,1 & MJ surplus \\
\hline
\end{tabular}

Fig. 6 shows results of grouping and weighing for $2 \mathrm{MW}$ wind power electric plants, both that based on land and offshore. A high level of harmful effects can be observed for life cycle of both the types of wind power plants in the category of fossil fuels ( for land-based one: $58.004 \mathrm{Pt}$; for offshore one : $41.712 \mathrm{Pt}$ ) as well as that of inorganic compounds impairing respiratory system (31.527 $\mathrm{Pt}$ and $24.846 \mathrm{Pt}$, respectively).

Fig. 7 illustrates results of grouping and weighing with taking into consideration the main damage categories, for land-based and offshore wind power electric plants. For life cycle of land-based wind power electric plant a higher level of harmful impact was obtained in the categories of human health $(46.590 \mathrm{Pt})$ and raw materials $(70.211 \mathrm{Pt})$, and, for offshore one - in the category of ecosystem quality $(12.905 \mathrm{Pt})$. A little higher total level of harmful effects onto the environment in all the damage categories is attributed to the land-based wind power electric plant (125.147 Pt), in comparison to that sited offshore (109.074 Pt).

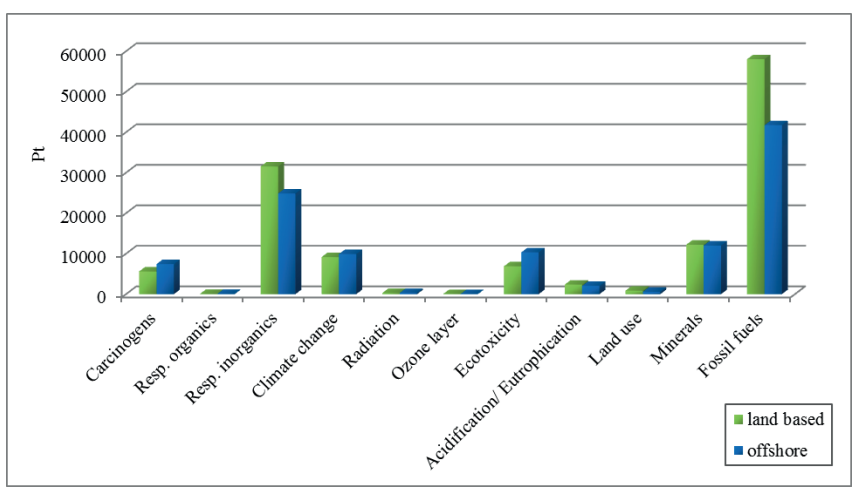

Fig. 6. Results of grouping and weighing for $2 M W$ wind power electric plants, both that based on land and offshore, by using Ecoindex-99 method and taking into account impact categories [acc.the authors' own work]

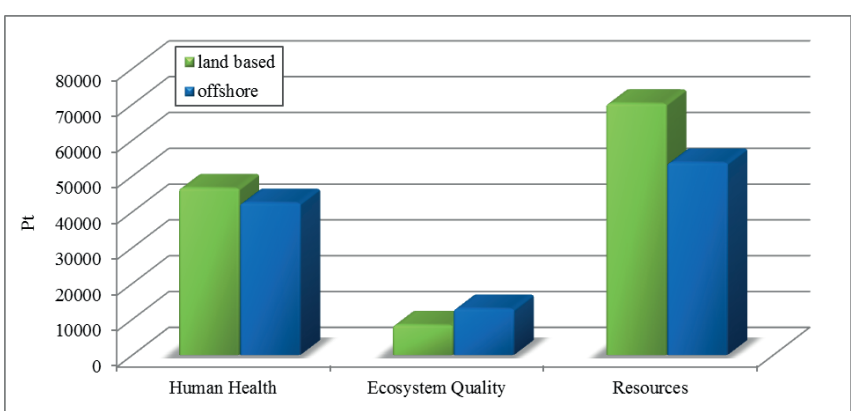

Fig. 7. Results of grouping and weighing for $2 M W$ wind power electric plants, both that based on land and offshore, by using Ecoindex-99 method and taking into account the main damage categories [ acc. the authors' own work]

\section{Summary and conclusions}

Due to a relatively simple principle of functioning and application of novel technologies the wind power industry has become one of the most important branches of renewable energy sector. As compared with the land wind power industry, the offshore wind power industry is distinguished by a higher operational effectiveness of turbines, resulting from a greater stability and force of wind blowing over sea regions, as well as a lack of any significant technological limitations as offshore - sited turbines can be much greater in size and more effecitve $[5,16]$.

During analysis of environmental impact of life cycle of $2 \mathrm{MW}$ wind power electric plant, both that based on land and offshore (with monopile tower) it has been demonstrated that a higher negative impact level is attributed to land-based one in six, out of eleven, impact categories. For both the types of wind power electric plants especially high negative impact levels have been found in the categories of fossil fuels and inorganic compounds impairing respiratory system. Negative impact level in the category of human health and raw materials resources was higher in case of the land-based wind power electric plant, whereas in the category of ecosystem quality - for offshore one. The total negative impact level during one life cycle (25 years) was only a little higher (about $16.000 \mathrm{Pt}$ ) in case of the land-based wind power electric plant, compared to offshore one. However it should be remembered that the results may differ depending on an applied kind of the anchoring of offshore wind power electric plant. 


\section{Bibliography}

1. ACKERMANN, T.: Transmission systems for offshore wind farms. Wind power in power systems, Stockholm: Royal Institute of Technology Stockholm, 2005.

2. BARLOW, J.: Innovation and learning in complex offshore construction projects, Research Policy, 7-8/2000, pp.973989.

3. carbontrust.com (access on: 2014-08-02)

4. CARMEL, E., AGARWAL, R.: The maturation of offshore sourcing of information technology work. Information Systems Outsourcing, 7/2006.

5. CHAKRABARTI, S.: Handbook of offshore engineering. Amsterdam: Elsevier, 2005.

6. COX, S.J., CHEYNE, A.J.T.: Assessing safety culture in offshore environments. Safety Science, 1-3/2000, pp. 111129.

7. ec.europa.eu (access on: 2014-08-02)

8. energetycznie.com.pl (access on: 2014-08-02)

9. ewea.org (access on: 2014-08-02)

10. FLIZIKOWSKI J., BIELIŃSKI K.: Design of environmental energy processors ( in Polish), Wydawnictwa Uczelniane ATR ( Publisher ), Bydgoszcz, 2000.

11. GILL, A.B.: Offshore renewable energy: ecological implications of generating electricity in the coastal zone. Journal of Applied Ecology, 4/2005, pp.605-615.

12. GUINEE J.B., GORRREE M.: Handbook on Life Cycle Assessment - Operational Guide to the ISO Standards. Kluwer Academic Publishers, 2002.

13. KORONOWICZ T., SZANTYR J.A.: Comparative analysis of the theoretical models of ideal propulsor, ideal fluid brake, ideal screw propeller and ideal axial wind turbine. Polish Maritime Research, No. 2(78), vol. 20 , 2013

14. LEWANDOWSKI, W.M., Proecological renewable energy sources ( in Polish ). Wydawnictwo Naukowo-Techniczne ( Publisher ), Warsaw , 2010.

15. MEARNS, K., WHITAKER, S.M., FLIN, R..: Safety climate, safety management practice and safety performance in offshore environments. Safety Science, 8/2003, pp. 641680 .

16. morskiefarmywiatrowe.pl
17. MUSIAL, W., BUTTERFIELD, S., RAM, B.: Energy from offshore wind. Texas: NREL, 2006.

18. OTREMBA Z., ANDRULEWICZ E.: Physical fields during construction and operation of wind farms by example of Polish maritime areas. Polish Maritime Research, No 4(84) 2014, vol 21.

19. PIASECKA I., TOMPOROWSKI A.: Impact of a wind power plants life cycle on the state of the atmosphere. Ekologia i Technika, No. 5/2013.

20. PIASECKA I: Development prospects for offshore wind farms ( in Polish). A chapter in the monograph : 7th „EkoEuro-Energia” [conference] on Engineering of Renewable Energy Sources , A. Mroziński Ed., Wydawnictwo Fundacji Rozwoju Mechatroniki ( Publisher ), ISBN 97883-938655-1-2, Bydgoszcz 2014, pp. 81-95

21. STRYJECKI, M., MIELNICZUK, K., BIEGAJ, J.: A guide over siting and environmental procedures for wind farms in Polish sea territories ( in Polish). Wyd. Fundacji na rzecz Energetyki Zrównoważonej (Publisher) Warsaw 2011

22. ULGIATI S., RAUGEI M., BARGIGLI S.: Overcoming the inadequacy of single-criterion approaches to Life Cycle Assessment. Ecological Modelling, vol. 190, 2/2006.

23. WIŚNIEWSKI, G., MICHAŁOWSKA-KNAP, K., DZIAMSKI, P., ONISZK-POPŁAWSKA, A., REGULSKI, P.: A vision of development of wind power industry in Poland up to 2020 ( in Polish). Wydawnictwo Polskiego Stowarzyszenia Energetyki Wiatrowej ( Publisher ), Warsaw 2009.

24. ŻÓŁTOWSKI M.: Assessment State of Masonry Components Degradation. Applied Mechanics and Materials Vol. 617(2014), Trans Tech Publications, Switzerland 2014, ISSN 1662-7482. pp. 142-147.

25. ŻÓŁTOWSKI M.: Investigations of harbour brick structures by using operational modal analysis. Polish Maritime Research, No. 1/ (81), vol.21, ISSN 1233-2585, 2014, pp. 42-54.

\section{CONTACT WIHT AUTHOR}

\author{
Adam Mroziński \\ Izabela Piasecka \\ University of Technology \\ and Life Sciences in Bydgoszcz \\ 7 Prof. Kaliskiego Al. \\ 85-796 Bydgoszcz \\ POLAND
}

